\title{
Variation patterns in individual fish responses to chemical stress among estuaries, seasons and genders: the case of the European flounder (Platichthys flesus) in the Bay of Biscay
}

\author{
Jean Laroche • Olivier Gauthier • Louis Quiniou • Alain Devaux • \\ Sylvie Bony • Estérine Evrard • Jérôme Cachot • Yan Chérel • \\ Thibaut Larcher • Ricardo Riso • Vianney Pichereau • \\ Marie Hélène Devier • Hélène Budzinski
}

Received: 30 April 2012 / Accepted: 22 October 2012

(C) Springer-Verlag Berlin Heidelberg 2012

\begin{abstract}
The objective was to describe and model variation patterns in individual fish responses to contaminants among estuaries, season and gender. Two hundred twentyseven adult European flounders were collected in two seasons (winter and summer) in four estuaries along the Bay of Biscay (South West France), focusing on a pristine system (the Ster), vs. three estuaries displaying contrasted levels of contaminants (the Vilaine, Loire and Gironde). Twenty-
\end{abstract}

Responsible editor: Philippe Garrigues

J. Laroche $(\bowtie) \cdot$ O. Gauthier $\cdot$ L. Quiniou $\cdot$ R. Riso $\cdot$ V. Pichereau Laboratoire des Sciences de l'Environnement Marin LEMAR, Institut Universitaire Européen de la Mer, Université Européenne de Bretagne, Université de Brest, UMR 6539 CNRS/UBO/IRD/ Ifremer,

29280 Plouzané, France

e-mail: jean.laroche@univ-brest.fr

A. Devaux $\cdot$ S. Bony

USC INRA "Impact génotoxique sur les hydrosystèmes",

UMR LEHNA 5023, ENTPE, Rue Maurice Audin,

69518 Vaulx en Velin Cedex, France

E. Evrard

CEDRE,

rue Alain Colas, CS 41836,

29218 Brest Cedex 2, France

J. Cachot $\cdot$ M. H. Devier $\cdot$ H. Budzinski

Université Bordeaux 1, EPOC UMR 5805, LPTC Group,

Avenue de la Libération,

33405 Talence, France

Y. Chérel · T. Larcher

UMR 703 INRA/Oniris,

Route de Gachet,

44307 Nantes Cedex 03, France three variables were measured by fish, considering the load of contaminants (liver metals, liver and muscle persistent organic pollutants, muscle polycyclic aromatic hydrocarbons); the gene expression (Cyt C oxydase, ATPase, BHMT, Cyt P450 1A1, ferritin); the blood genotoxicity (Comet test); and liver histology (foci of cellular alteration-tumour, steatosis, inflammation, abnormal glycogen storage). Canonical redundancy analysis (RDA) was used to model these variables using gender, season and estuary of origin as explanatory variables. The results underlined the homogeneity of fish responses within the pristine site (Ster) and more important seasonal variability within the three contaminated systems. The complete model RDA was significant and explained $35 \%$ of total variance. Estuary and season respectively explained 30 and $5 \%$ of the total independent variation components, whilst gender was not a significant factor. The first axis of the RDA explains nearly $27 \%$ of the total variance and mostly represents a gradient of contamination. The links between the load of contaminants, the expression of several genes and the biomarkers were analysed considering different levels of chemical stress and a possible multi-stress, particularly in the Vilaine estuary.

Keywords Estuaries · Pollution · European flounder · Gene expression $\cdot$ Biomarkers $\cdot$ Liver pathology

\section{Introduction}

The use of biomarkers (biochemical, cellular, physiological or behavioural variables that can be measured in tissue or body fluid samples or at the level of whole organisms to 
provide evidence of exposure and/or effects from one or more contaminants; Depledge 1994) as surrogate measures of biological impact within field studies has been prevalent for many years. The Water Framework Directive (WFD by the Commission of the European Union: EU 2000/60/EC) has shifted its emphasis away from primarily monitoring chemicals to an approach that incorporates both chemical and ecological objectives and is designed to protect the structure and functions of aquatic ecosystems (Hagger et al. 2006). These last years, an increasing number of studies are combining approaches of monitoring chemical contaminant levels with measurements of biological response related to pollutants effects, allowing the assessment of environmental status across European marine regions (Hagger et al. 2008; Thain et al. 2008; Lyons et al. 2010).

One of the major problems when making ecological predictions based on biomarker analyses is that few studies have taken into account how biomarkers are able to separate the effects of anthropogenic stressors from that due to variable natural processes (Hagger et al. 2006); environmental factors such as temperature, salinity, turbidity, diet and season may contribute to biomarker variation by the alteration of pollutant bioavailability or by the regulation of natural biological changes such as growth and reproductive state (Martinez-Gomez et al. 2010; ICES 2011; Tankoua et al. 2011; Höher et al. 2012; Guimaraes et al. 2012). A further confounding issue in natural systems is associated with the genetic differences between individuals and/or populations and their adaptability/adaptation to different habitats. Thus, to address these confounding factors, biomarker analyses should consider the following parameters: reproductive state, sex, age and region of origin (particularly important for interpreting spatial information across wide geographical areas; Thain et al. 2008). Ideally, contaminant load and responses from the subcellular (e.g. molecular responses, DNA damages, etc.) to the organismal level (e.g. growth, disease occurrence, etc.) should also be assessed in order to fully explore possible cause-and-effect relationships between chemical stress and biological responses.

The European flounder (Platichthys flesus) is considered as a pertinent sentinel species for water quality monitoring in coastal marine systems (SGIMC 2011); thus, numerous studies have assessed the biological effects of contaminants on P. flesus (Vethaak and Wester 1996; Stentiford et al. 2003; Lyons et al. 2004; Vethaak et al. 2011). In the present study, we have conducted a holistic approach on the responses of the European flounder to chemical stress in the field, focusing on four estuaries along the Bay of Biscay (Southwest France), a system characterized by reduced pollution (the Ster), and three estuaries displaying higher levels of contaminants (the Vilaine, Loire and Gironde). The objective was to describe and model the variation patterns in individual fish responses to contaminants among estuaries, analysing contaminant loads, molecular and cellular markers and whole organism responses considering two seasons and a possible gender-related effect.

\section{Materials and methods}

\section{Study sites and fish sampling}

The four estuaries are located in the Bay of Biscay (Fig. 1). The northern Ster estuary was considered as a moderately contaminated site, displaying low domestic, agricultural and industrial effluents (Marchand et al. 2004). On the other hand, the Vilaine, Loire and Gironde estuaries were clearly impacted by chemical stress. The Vilaine catchment was characterized by important impacts of agriculture and, thus, by higher levels of pesticides, but was also submitted to important winter polycyclic aromatic hydrocarbon (PAH) contaminations and to a chronicle hypoxia in summer (Forget 1998; Menesguen et al. 2001; Evrard et al. 2010a). Finally, the Loire and Gironde showed a diffuse

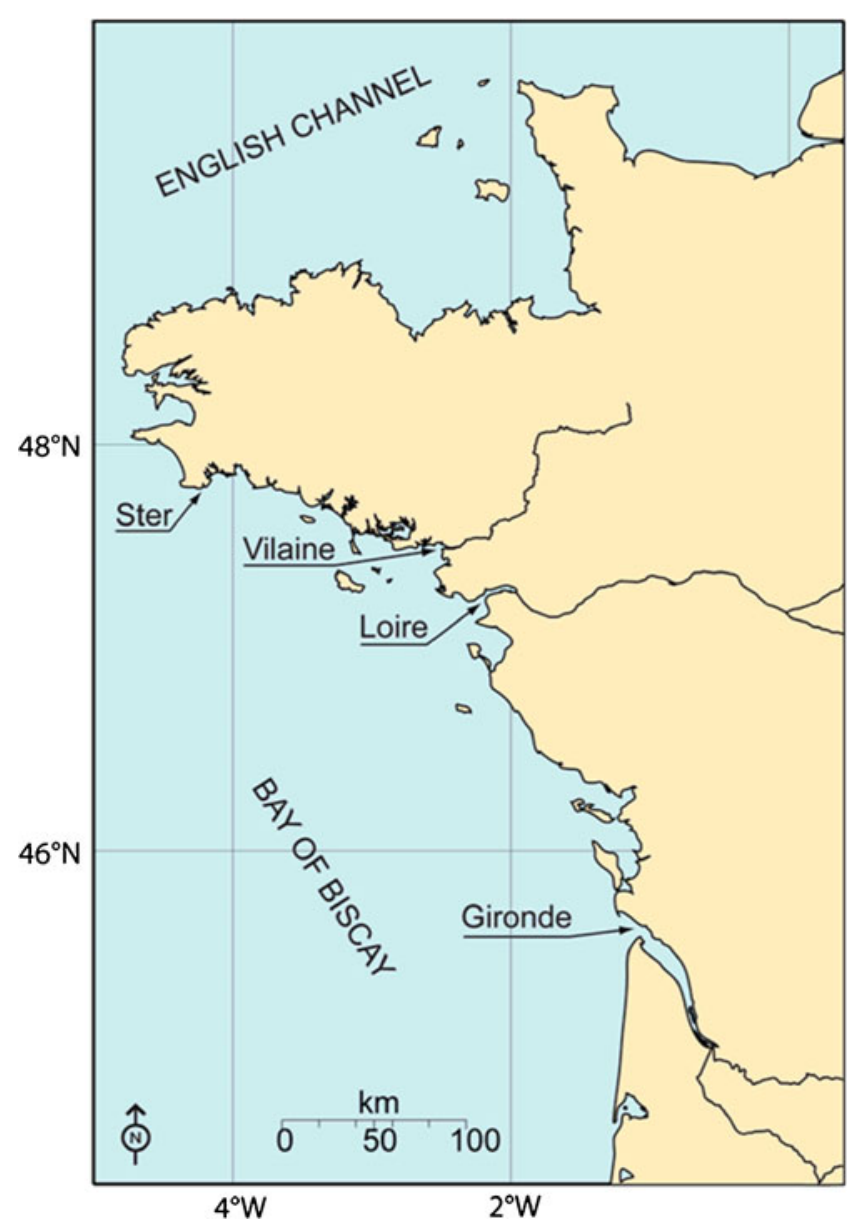

Fig. 1 Sampling sites in three contaminated estuaries (Vilaine, Loire, Gironde) and one reference estuary (Ster) 
contamination characterized by a mixture of metals, PAHs, polychlorobiphenyls (PCBs) and pesticides (Tapie 2006; Evrard et al. 2010a).

The fish sampling operations were conducted with a beam trawl (stretch mesh size, $70 \mathrm{~mm}$; trawling speed, 2 knots in $20 \mathrm{~min}$ ). Adults were targeted during two seasons: the reproduction period in winter (January 2005 in the Vilaine, Loire and Gironde; January 2006 in the Ster) and the sexual rest period in summer (July 2005 in the Vilaine, Loire and Gironde; July 2006 in the Ster). Fish length ranged from 20 to $42 \mathrm{~cm}$. Average ages estimated by otolith observation were, respectively for the Vilaine, Loire, Gironde and Ster, $2.8 \pm 0.3$, $3.2 \pm 0.2,3.3 \pm 0.2$ and $1.9 \pm 0.1$ years.

Fish were anesthetized with MS-222 and blood was collected in heparinized syringes from the caudal vessel, diluted in a cryopreservative buffer and deep frozen in liquid nitrogen. The reduced concentration of MS-222 (100 mg/l) and the limited exposure time $(15 \mathrm{~min})$ do not induce primary DNA damage in fish (Barreto et al. 2007). After blood collection, fishes were knocked out and fragments of liver and muscle were quickly dissected and snap-frozen in liquid nitrogen (Evrard et al. 2010a). Otoliths were extracted from the skull and preserved in plastic bags until use.

Chemical analysis in fish tissues

\section{Metals}

Liver samples (100 mg wet weight) were dissolved in $2 \mathrm{ml}$ nitric acid $(65 \%)$. After dilution in $0.5 \mathrm{M} \mathrm{NaCl}$, the concentrations of copper, lead and cadmium were assessed using stripping chronopotentiometric methods (Riso et al. 1997a, b; Evrard et al. 2010a).

\section{Organic contaminant in tissues: muscle and liver}

Freeze-dried tissues were extracted using microwaveassisted extraction with dichloromethane $(30 \mathrm{~W}, 10 \mathrm{~min})$ according to the protocols developed by Budzinski et al. $(1995,2000)$ or by ASE according to the protocol developed by Tapie et al. (2008). The internal standards were gravimetrically added prior to the extraction, and one extraction blank was performed with each series of extraction.

PCBs/PBDEs/lindane PCBs (CB 28, CB 52, CB 101, CB 118, CB 138, CB 153 and CB 180); polybrominated diphenyl esters (PBDEs; BDE 47, BDE 99, BDE 119, BDE 153); and lindane contamination was assessed in muscle and liver.

For PCB analysis (Thompson et al. 1999), the extract was then purified by shaking with sulphuric acid. The organic phase was neutralised with deionised water, dried on anhydrous sodium sulphate and reconcentrated. A second purification step on silica micro-columns was performed. PCBs, PBDEs and lindane were eluted with a mixture of pentane/dichloromethane $(90: 10, v / v)$. The final extract was reconcentrated in isooctane and analysed by gas chromatography coupled to an electron capture detector (GC-ECD). PCB congeners 30, 103, 155 and 198 were used as internal standards.

A particular focus was also conducted on the ratio $\mathrm{CB}$ $118 / \mathrm{CB} 153$. On the one hand, CB 118 is classified by Kannan et al. (1995) as a congener that could be metabolized by the cytochrome P-450 1A subfamily (group III); on the other hand, CB 153 is considered as a non-metabolizable congener (group I), a tracer of the bioaccumulation process. The ratio CB 118/CB 153 can be used as a proxy of the CB 118 metabolism (Tapie et al. 2011).

Polycyclic aromatic hydrocarbons For PAH analysis (Baumard et al. 1999), the extract was directly reconcentrated. A purification step on alumina and silica microcolumns was performed. The extract was passed through the alumina column and PAHs were further eluted with dichloromethane. The sample was then loaded onto the silica column. The aliphatic fraction eluted with pentane was discarded and PAHs were then eluted with a mixture of pentane/ dichloromethane $(65: 35, v / v)$. The final extract was reconcentrated in isooctane and analysed by gas chromatography/ mass spectrometry (GC-MS). Perdeuterated phenanthrene, fluoranthene, chrysene benzo $[e]$ pyrene, benzo $[a]$ pyrene and benzo $[g h i]$ perylene were used as internal standards.

Quality control To test the accuracy and the validity of the quantification method, standard solutions (on one hand for PAHs and, on the other hand, for PCBs, PBDEs and lindane) of compounds to be quantified mixed with the related internal standards are regularly run on the GC-MS and GCECD systems. These solutions are used, on the one hand, to calculate the response factors; on the other hand, other independent solutions are used to test the precision of the quantification which has been evaluated to be comprised between 90 and $107 \%$ depending on the compounds, with reproducibilities between 2 and $6 \%$. Moreover, the entire analytical procedure was applied several times to the certified mussel tissue, SRM 2974 (NIST, Gaithersburg, MD, USA). The recoveries for five replicates on this SRM were between 70 and $110 \%$, with reproducibilities ranging from 7 to $17 \%$ depending on the compounds.

\section{Biological responses}

\section{Molecular responses: gene expression by RT-PCR}

Livers samples from P. flesus were homogenized in guanidium isothiocyanate using an Ultra Turrax; thus, sodium acetate $(3 \mathrm{M})$, chloroforme (1/5 volume) and phenol (2 volumes) were added. Samples were shaken and 
refrigerated for $15 \mathrm{~min}$ on ice. Centrifugation $(12,000 \times \mathrm{g}$, $20 \mathrm{~min}, 4^{\circ} \mathrm{C}$ ) followed, and the supernatant was recovered and precipitated with 2.2 volumes of pure frozen ethanol. Samples were shaken and left at $-20{ }^{\circ} \mathrm{C}$ overnight. Total RNA was recovered by centrifugation $(12,000 \times g, 30 \mathrm{~min}$, $4{ }^{\circ} \mathrm{C}$ ) and the pellet was washed with ethanol $70 \%$. Finally, the pellet was dried and resuspended in diethyl pyrocarbonate. Optical densities (ODs) were measured at $260 \mathrm{~nm}$ using a spectrophotometer, and concentrations were quantified using $1 \mathrm{OD}=40 \mu \mathrm{g}$ RNA. RNA integrity was checked by electrophoresis on agarose.

Reverse transcription was performed on $20 \mu \mathrm{g}$ of total RNA using oligodT primer and M-MLV reverse transcriptase (Promega). One microgram of cDNA was amplified in $2 \mathrm{mM}$ of $\mathrm{MgCl}_{2}$ and $4 \mathrm{pM}$ of primers $\mathrm{F}$ and $\mathrm{R}$ for each gene. Target genes were BHMT, cytochrome c oxidase subunit 2, ATPase Fo subunit 6, ferritin and Cyp450 1A1. Ribosomal 18S was used as the polymerase chain reaction internal control and amplified with $10 \mathrm{pM}$ of primers $\mathrm{F}$ and $\mathrm{R}$; primers and the conditions of the amplification of genes used in this semiquantitative gene expression study are available in Evrard et al. (2010a). The resulting PCR products were electrophoresed in $0.5 \times \mathrm{TBE} / 1.5 \%$ agarose gel and visualized with ultraviolet radiation after staining with ethidium bromide. Images were analysed with the GeneProfiler software (version 4.03, Scanalytics, Inc., Lincoln, NE, USA). OD for each band (PCR product) was measured. The results are given as the ratio of OD gene/OD internal control.

\section{Cellular responses: genotoxicity assessment by the Comet assay}

The level of DNA breaks induced by chemicals is considered as a precocious and sensitive biomarker for populations living in contaminated aquatic systems (Frenzili et al. 2009). In this study, the Comet assay was carried out on flounder erythrocytes according to the procedure described by Singh et al. (1988), with slight modifications detailed in Evrard et al. (2010a). After cell treatment and electrophoresis, DNA was stained with $0.05 \mathrm{mM}$ ethidium bromide and scored using an Axioskop epifluorescence microscope (Zeiss) and the Comet assay IV image analysis system (Perceptive Instruments Ltd., Havrevill, UK). Randomly selected cells from two replicated slides (50 cells per slide) were analysed. Among the different available parameters, the tail moment (product of tail migration and tail intensity) was measured for each cell.

\section{Condition index and growth rate}

The condition factor linked to energy reserves was estimated using the relation

$K=W / L^{3}$ where $W$ (in grams) and $L$ (in centimetres) are respectively the somatic weight and the total fish length.

Sagitta, the biggest otolith in fish, was used for the estimation of growth rate (GR). GR was assessed by backcalculation between the beginning of the first fish winter (L1) and the beginning of its second winter (L2). Three otolith parameters were measured through image processing (UTHSCA Image Toll v.2): the maximum radius or maximum distance from the nucleus to the periphery $(R)$; the radius at the beginning of the first winter (R1) and the radius at the beginning of the second winter (R2). Fish length at different lifetimes was estimated considering the relationship between the total length $(L \mathrm{t})$ of a fish and the total otolith radius $R: L \mathrm{t}=a R+b$ (with $a$ and $b$ as constants). Thus, GR was back-calculated as: $\mathrm{GR}=\mathrm{L} 2-\mathrm{L} 1$.

\section{Liver histology}

Portions of liver were collected immediately after removing the liver in the field and fixed in $10 \%$ formalin for histology. Fixed tissues were embedded in wax and cut into $4-\mu \mathrm{m}$ sections. Sections were stained with haematoxylin-eosinsaffron using conventional protocol according to the ICES guidelines (Feist et al. 2004). The histological structure of normal flounder liver is a regular network of tubules of hepatocytes with a central bile canaliculus separated by sinusoids. Bile ducts and pancreatic tissue are also present in the liver parenchyma (Vethaak and Wester 1996).

In the present study, all liver lesions were reported by a skilled ECVP-certified pathologist and assigned to five main categories recommended for monitoring the biological effects of contaminants in flatfish species: parasitic lesions, inflammation, necrosis/regeneration, foci of cellular alteration and neoplasms (Feist et al. 2004). A detailed description of flounder liver pathology was given in Cachot et al. (2012). Storage disorders are characterized by large accumulation of lipid (steatosis) or glycogen in hepatic cells. Normal glycogen accumulation generates a pale cytoplasmic appearance with, at most, a mild increase of the cell size. Abnormal glycogen storage completely masks the cytoplasmic components of the cell and generates a marked increase of the cell size. Some cell damages should be observed in association with an abnormal cytoplasmic accumulation of glycogen, as apoptosis/necrosis. Inflammation is characterized by an infiltration of lymphocytes and macrophages in the liver parenchyma mainly observed at the vicinity of the major blood vessels. Foci of cellular alterations (FCA) are composed of small groups of hepatocytes with abnormal morphology and staining characteristics but without compression of the surrounding tissue. According to their coloration, five different FCA categories can be distinguished: vacuolated foci, clear cell foci, eosinophilic foci, basophilic foci and mixed cell foci. They are 
considered as putative preneoplastic lesions. Tumours are characterized by cellular atypia associated with architectural abnormalities such as tubular, acinar or solid growth pattern. The tumour growth is associated with a compression of the surrounding tissue (benign) or infiltration of it (malignant).

Data analysis

Twnty-five response variables were analysed per fish in the different estuaries: 13 pollutant concentrations in fish tissue, 5 molecular and 1 cellular response, and, finally, 6 whole organism responses (Table 1). The intention was to describe and model the variation patterns in individual responses to contaminants among estuaries, season and gender. These were thus used as categorical independent variables in all analysis.

As some response variables could not be assessed for all of the 253 captured individuals, missing data occurrence across individuals and variables was evaluated. Given the observed pattern, it was decided to remove 26 individuals from the analysis. Indeed, 20 measurements were missing for 1-17 individuals, with a majority of those $(15 / 20)$ missing for 15 specimens. These individuals where not distributed homogeneously among estuaries, but given the sampling effort in each, this yielded a practically balanced

Table 1 Load of contaminants: heavy metals in liver and organic pollutants in liver (l) and muscle (m)

\begin{tabular}{|c|c|c|c|}
\hline \multirow{2}{*}{$\begin{array}{l}\text { Load of } \\
\text { contaminants }\end{array}$} & \multicolumn{3}{|l|}{$Y$} \\
\hline & $\begin{array}{l}\text { Molecular } \\
\text { responses }\end{array}$ & $\begin{array}{l}\text { Cellular } \\
\text { response }\end{array}$ & $\begin{array}{l}\text { Whole organism } \\
\text { responses }\end{array}$ \\
\hline $\mathrm{Cu}^{\mathrm{a}}$ & CytC. $18 \mathrm{~S}^{\mathrm{a}}$ & Comet $^{\mathrm{a}}$ & $\mathrm{K}$ \\
\hline $\mathrm{Pb}^{\mathrm{a}}$ & BHMT.18S ${ }^{\mathrm{a}}$ & & $\mathrm{GR}^{\mathrm{a}}$ \\
\hline $\mathrm{Cd}^{\mathrm{a}}$ & CytP450.18S $\mathrm{S}^{\mathrm{a}}$ & & Glyc. storage \\
\hline LINDANE.1 & Ferritin. $18 \mathrm{~S}^{\mathrm{a}}$ & & Steatosis \\
\hline LINDANE.m & ATPase. $18 \mathrm{~S}^{\mathrm{a}}$ & & Inflam. \\
\hline PCB. $1^{\mathrm{a}}$ & & & FCA-tumour \\
\hline PCB.m & & & \\
\hline PCB118:PCB153.1 & & & \\
\hline PCB118:PCB153.m & & & \\
\hline PBDE.1 & & & \\
\hline PBDE.m & & & \\
\hline PAH.m & & & \\
\hline PYR.m & & & \\
\hline
\end{tabular}

Molecular responses: relative expression of five liver transcripts (OD transcript/OD 18S). Cellular response was assessed by the Comet assay: DNA damage expressed as the mean tail moment in erythrocytes. Whole organism responses: condition index $(K)$; growth rate (GR); and liver histology (abnormal glycogen storage, steatosis, inflammation, foci of cellular alterations or tumour)

${ }^{\text {a }}$ Chemical and biological markers analysed in a previous study (Evrard et al. 2010a) considering the average patterns between estuaries dataset among estuaries (Table 2). A similar pattern was obtained among seasons, but the effort was more unbalanced when considering gender (Table 2). An average of 28.4 individuals were analysed in each estuary and season combination.

The frequency distribution of the 21 quantitative variables was assessed and $\log (x+\min (x))$ transformation was applied to each in order to obtain more symmetric distributions. The transformation was very successful for the majority of variables, but LINDANE.m, LINDANE.1, PBDE.m, PBDE.1, PYR.m, BHMT.18S, CytP450.18S and ATPase.18S still exhibited some degree of skewness. All quantitative data were standardized (zero mean, unit variance) before further analysis.

In order to assess whether individuals from the respective estuaries, seasons and genders formed more or less homogeneous (spherical) groups in terms of their response to exposure to contaminants, $k$-means partitioning was performed. Partitioning in $k=2$ to $k=16$ groups was performed $(1,000$ iterations for each value of $k)$ and the CalinskiHarabasz (CH; Calinski and Harabasz 1974) criterion computed to tentatively identify the optimal number of groups. Partitions were cross-tabulated with specimen identity (estuary, season, gender) to assess congruence.

Variation partitioning among estuary, season and gender was performed to evaluate the contribution of these different components to the model (Borcard et al. 1992; Legendre 2007). This approach was originally developed for partitioning ecological variation among environmental and spatial components. It relies on multiple linear regressions and partial multiple regressions for a univariate response and on (canonical) redundancy analysis (RDA; van den Wollenberg 1977) and partial RDAs (ter Braak 1988) in the multivariate case. Fractions of explained variation are reported as adjusted canonical coefficients of determination $\left(R_{a}^{2}\right.$; Peres-Neto et al. 2006). The significance of RDAs was tested by permutation of the reduced model (i.e. permutation

Table 2 Sample size for the entire dataset and broken down according to the categorical variables used in the analysis (estuary, season, gender)

\begin{tabular}{lrrr}
\hline & Sampled & Removed & Analysed \\
\hline Total & 253 & 26 & 227 \\
Ster & 58 & 1 & 57 \\
Vilaine & 65 & 11 & 54 \\
Loire & 65 & 7 & 58 \\
Gironde & 65 & 7 & 58 \\
Summer & 120 & 10 & 110 \\
Winter & 133 & 16 & 117 \\
Male & 100 & 2 & 98 \\
Female & 153 & 24 & 129 \\
\hline
\end{tabular}


of the residuals after removing the effect of conditioning variables). Some fractions of variation can only be obtained by subtraction and cannot be tested for significance. Coding categorical variables as described in Legendre and Anderson (1999) allowed to also test the significance of the interaction terms. A forward selection of explanatory variables was performed (Blanchet et al. 2008).

Within-group (estuary, season) multivariate dispersion of individuals was estimated by way of within-group mean Euclidean distance to group centroid. All other analyses ( $k$-means and RDA) also preserve Euclidean distances among objects.

All analyses were conducted within the $\mathrm{R}$ environment (R Development Core Team 2010). Missing data pattern evaluation relied on the VIM package (Templ et al. 2010) and group congruence visually evaluated with the vcd package (Meyer et al. 2010). The vegan (Oksanen et al. 2010) and packfor (Dray et al. 2009) packages were used for multivariate analysis.

\section{Results}

Using the $\mathrm{CH}$ criterion, $k$-means partitioning did not allow an objective determination of the optimal number of groups because $\mathrm{CH}$ was maximized for $k=2$ and had a monotonic decrease with an increase in $k$. We thus investigated the results for $k=4$ only (Fig. 2), corresponding to the number of estuaries, and cross-tabulated these a posteriori groups with those formed a priori by the factors of interest (estuary, season, gender, and combinations thereof).

The most striking result is that one KM group (group 4) contains only individuals from the Ster and all but one of those from this estuary. Also, individuals from the Ster (group 4) aggregate regardless of season (Fig. 2), but this factor is correlated with membership in group 2 (Vilaine, Loire and Gironde, mostly winter), group 3 (Vilaine, summer) and group 1 (Loire and Gironde, mostly summer). Indeed, these clusters hint that individuals sampled from the Vilaine in the summer (group 3) exhibit a different response to environmental stress compared to fish from the Loire and Gironde during the same season (group 2).

This highlights the homogeneity of responses within the Ster and more important seasonal variability within the other three estuaries, especially the Vilaine, and marked differences between the Ster and other estuaries in terms of overall response. Indeed, within-group multivariate dispersion is similar for the Loire $(\bar{x}=3.49, s=0.80)$, Ster $(\bar{x}=3$ $.70, s=0.63)$ and Gironde $(\bar{x}=3.72, s=0.79)$, but higher for the Vilaine $(\bar{x}=4.41, s=1.06)$. Within-group multivariate dispersion was similar between summer $(\bar{x}=4$ $.49, s=0.90)$ and winter $(\bar{x}=4.43, s=1.22)$. No clear pattern appears to segregate the individuals according to gender among the KM groups. Within-group multivariate dispersion was homogeneous for groups obtained from all estuary, season and gender combinations $(F=$ 1.216, $p>0.05)$, which allowed us to proceed with the next step of the analysis.
Fig. 2 Tile plot showing the distribution of individuals in a posteriori $k$-means groups $(k=$ $4)$ cross-tabulated with factor constraints used in the analysis (estuary, season, gender). Squared area of tiles is proportional to the number of individuals they contain. For example, group 4 contains 16 males and 13 females sampled during the summer in the Ster as well as 11 males and 15 females sampled from the same estuary during winter. A single male sampled from the Ster in winter ends up in group 3. Group numbering is arbitrary

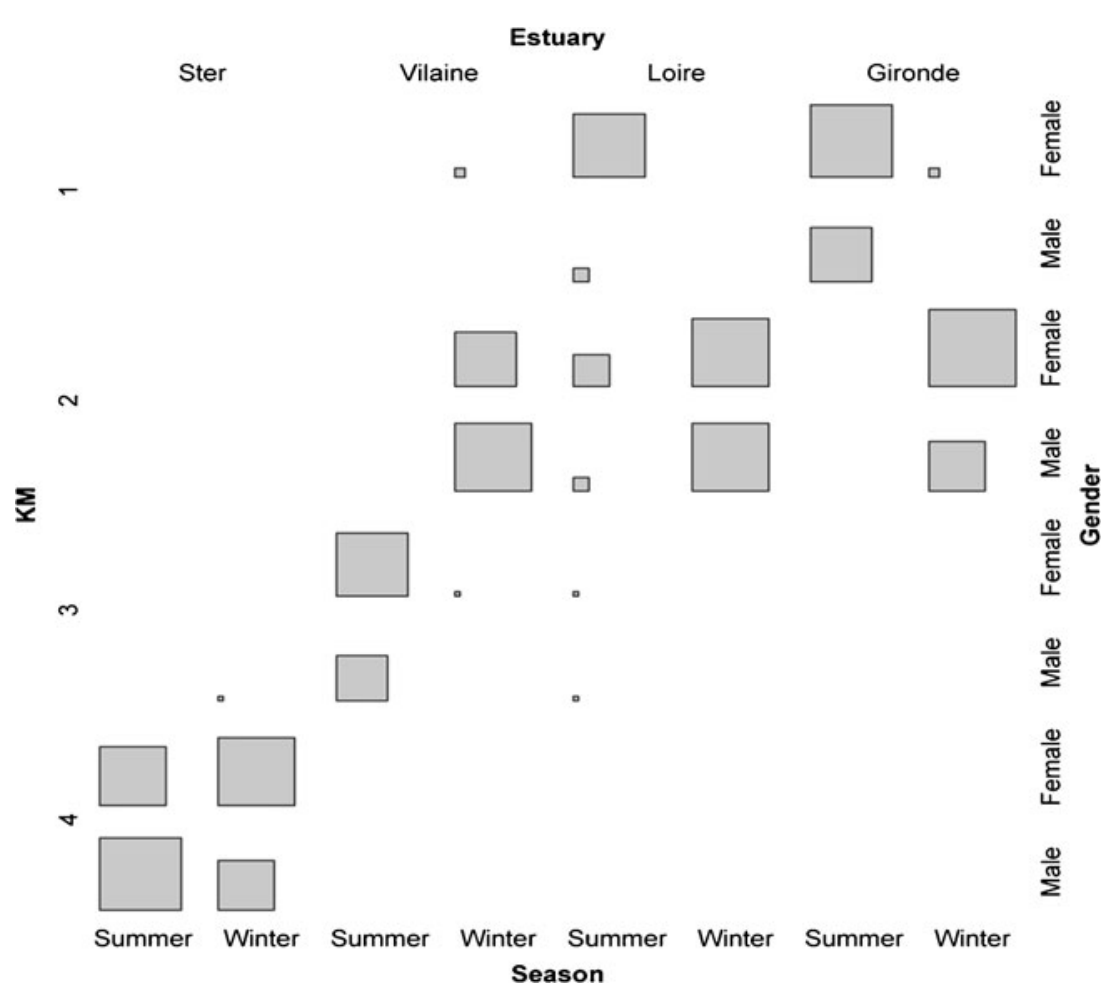


Interaction among the constraining factors was significant $\left(R_{a}^{2}=0.077, F=2.893, p<0.05\right)$. Forward selection among the interaction variables revealed that this is attributable to the interaction between estuary and season $\left(R_{a}^{2}=0\right.$ $.067)$. This reflects the pattern observed in Fig. 2 where individuals from the Ster show less variability in their response between seasons than those from the three other estuaries. Notwithstanding, and for simplicity's sake, since testing for the effect of season within estuaries and testing for that of estuaries within seasons revealed the same patterns, we present the RDA results without including the interaction terms (Fig. 3 and Table 3).

The complete model RDA for estuary, season and gender was significant and explained $35 \%$ of the total variance (Fig. 3 and Table 3). Variation partitioning revealed that estuary and season explained 30 and $5 \%$ of the total independent variation components, respectively, whilst gender was not a significant factor explaining variability in responses to contamination (Fig. 3 and Table 3). In the correlation biplot (Fig. 3), the distance between factor centroids and individuals is not a representation of the Euclidean distances among these objects.

Furthermore, a forward selection among the variables of the significant global model recoded as binary variables revealed two particularly interesting results: (1) all estuaries and seasons were accounted for in the reduced model which consisted of three estuary variables and one season variable and (2) whether an individual originated from the Ster or not alone accounted for $R_{a}^{2}=0.20$ of the total variation $(F=58.64, p=0.001)$.

The first axis of the RDA explains nearly $27 \%$ of total variance and mostly represents a gradient of contamination, from the Ster to the Vilaine, Loire and, finally, Gironde (Fig. 3a). RDA axis 2 explains a mere (but significant)

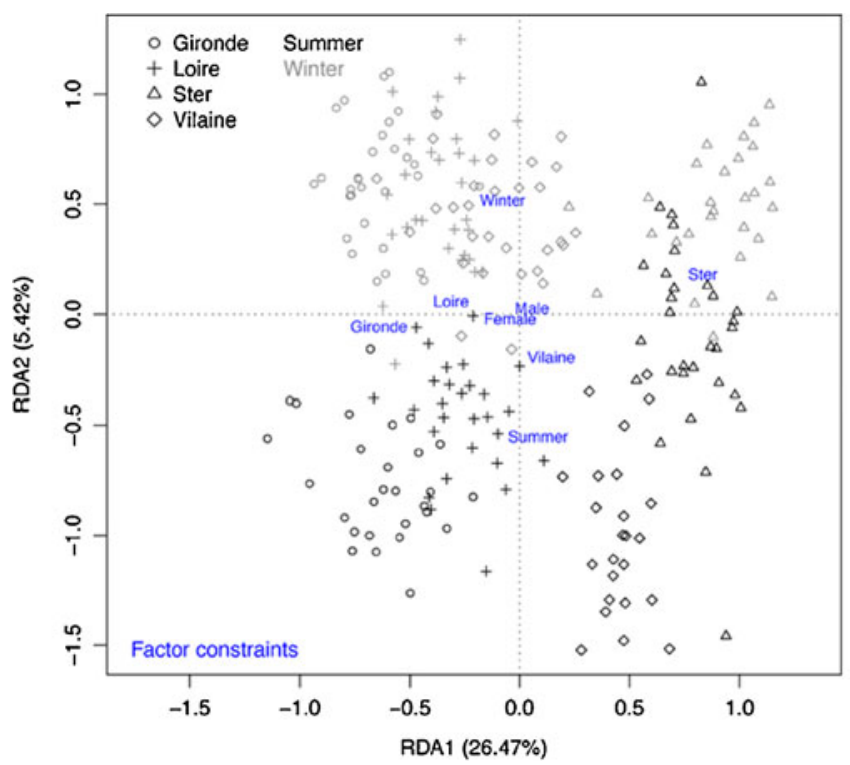

$5.42 \%$ of the total variance and represents the withinestuary differential response to contaminants among seasons (Fig. 3a).

With the exception of COMET, FERRITINE.18S, BHMT.18S and, to a lesser degree, LINDAME.m, ATPase.18S and CytP450.18S, all dependent variables were highly correlated among themselves and with the first axis of the RDA (Fig. 3b). Among the latter, CytC.18S and CB188: CB153 in the liver and muscle and GR, $\mathrm{K}$ and LINDANE.1 were positively correlated with axis 1 ; all others, negatively.

Thus, in the Ster and Vilaine, individuals were in better condition $(K)$, had better GRs, higher concentrations of liver lindane, higher expression levels of CyC.18S and elevated CB188:CB153 ratios. Individuals from the Gironde and Loire, on the other hand, had higher concentrations of most contaminants (PCB.m, PCB.1, PYR.m, PAH.m, PBDE.1, PBDE.m, $\mathrm{Cd}, \mathrm{Pb}, \mathrm{Cu}$ ).

Higher expression levels were observed in the winter for the ferritin and in the summer for the BHMT. COMET had higher values in the summer months (Fig. 3b). Finally, some variables were equivalently correlated with axes 1 and 2 : the activity of ATPase.18S (+, -), CytP450.18S (-, -) and LINDANE.m $(+,+)$.

The liver histology variables (storage disorders, inflammation, FCA-tumour) were close to the center of the RDA main plan (axes 1 and 2); thus, they were not localized on this plan. Thus, in our data set, the liver pathology did not contribute significantly to the differentiation between estuarine populations.

\section{Discussion}

The complete model established by our canonical RDA was significant and explained $35 \%$ of the total variance of

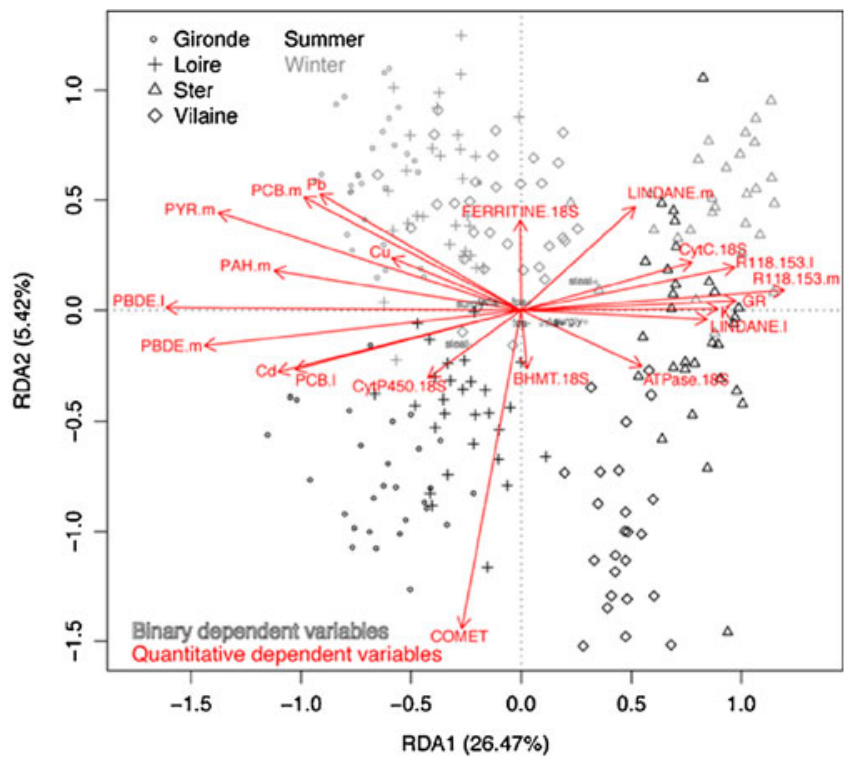

Fig. 3 Correlation biplot of complete RDA model. Axes 1 and 2 together explain $31.89 \%$ of the total variance. See Table 3 for explained variation and significance of fractions 
Table 3 Partition of variation among estuary, season and gender

\begin{tabular}{|c|c|c|c|c|c|}
\hline Matrices & $d f$ & $R^{2}$ & $R_{a}^{2}$ & $F$ & $p$ \\
\hline Estuary (E) & 3 & 0.309 & 0.299 & 33.176 & $0.005 * *$ \\
\hline Season (S) & 1 & 0.056 & 0.053 & 13.466 & $0.005 * *$ \\
\hline Gender $(\mathrm{G})$ & 1 & 0.006 & 0.002 & 1.470 & $0.140 \mathrm{NS}$ \\
\hline EuS & 4 & 0.364 & 0.353 & 31.779 & $0.005 * *$ \\
\hline$E \cup G$ & 4 & 0.313 & 0.301 & 25.316 & $0.005 * *$ \\
\hline$S \cup G$ & 2 & 0.063 & 0.055 & 7.557 & $0.005 * *$ \\
\hline$E \cup S \cup G$ & 5 & 0.369 & 0.354 & 25.814 & $0.005 * *$ \\
\hline \multicolumn{6}{|c|}{ Individual fractions } \\
\hline $\mathrm{E} \mid \mathrm{S} \cup \mathrm{G}$ & 3 & - & 0.300 & 35.648 & $0.005 * *$ \\
\hline $\mathrm{S} \mid \mathrm{E} \cup \mathrm{G}$ & 1 & - & 0.054 & 19.410 & $0.005 * *$ \\
\hline $\mathrm{G} \mid \mathrm{E} \cup \mathrm{S}$ & 1 & - & 0.002 & 1.606 & $0.058^{\text {N.S }}$ \\
\hline
\end{tabular}

Only fractions of interest are presented

$d f$ degrees of freedom, $R^{2}$ unadjusted coefficient of canonical determination (not given for partial analysis), $R_{a}^{2}$ adjusted $R^{2}, F$ pseudo- $F$ statistic, $p p$-value under a reduced permutation model, $\cup$ denotes the union of matrices, $\mathrm{A} \mid \mathrm{B}$ the partial RDA obtained for A after removing $\mathrm{B}, N S$ not significant

$* * p<0.001$

individual fish responses to chemical stress, considering four estuaries and two seasons. In this study, contaminant loads and biological responses measured from the molecular to the whole organism levels were assessed on the same individuals to explore the possible cause-and-effect relationships between environmental stress and fish responses. Variation partitioning showed that estuary and season respectively explained 30 and $5 \%$ of independent variance components, whilst gender was not a significant factor. Interaction between estuary and season explained a further independent $6.7 \%$ of the total variance.

On the first axis of the correlation biplot of the complete RDA model, a clear gradient of contamination appears from the less polluted site (Ster), to the contaminated system (Vilaine) and the heavily polluted systems (Loire and Gironde); these last two estuaries exhibited the highest contaminant loads in fish tissues, particularly concerning the bioaccumulation of heavy metals, PCBs and PBDEs in liver tissue. Generally, most PAHs are efficiently metabolized in fish tissues, and measuring metabolites in the bile is usually preferred (Thain et al. 2008); however, Fig. 3 shows a general increase of PAHs and pyrene levels in muscle tissue from the Ster (with the lowest levels) to the Vilaine, Loire and Gironde systems (with the highest levels). This trend confirms our previous analysis of the same individuals, but focusing on a single PAH metabolite: 1-hydroxypyrene (Evrard et al. 2010a). The halogenated aromatic hydrocarbon pesticide lindane was detected, particularly in the Ster and Vilaine systems, in drainage basins dominated by agriculture activities.
The main axis of the RDA underlined two opposite gradients. In the first place, the contamination gradient was inversely correlated with (1) the expression levels of two major genes of the mitochondrial electron transport chain (cytochrome C oxydase and ATPase), (2) the condition index and (3) the growth rate. Numerous pollutants affect the mitochondrial bioenergetics and gene expressions of key mitochondrial proteins in mollusks and fishes (Sokolova et al. 2005; Cambier et al. 2009); thus, we suggest that the downregulation of flounder Cyt $\mathrm{C}$ oxydase and ATPase in polluted estuaries could reduce the capacity of populations to maintain their energy production and, thus, lead to a reduction of the condition index and the growth rate. A possible negative impact on these fitness-related traits could be particularly felt in heavily contaminated systems where individuals need supplementary energy for cellular protection and maintenance. Indeed, in another catadromous fish, the declining European eel (Anguilla anguilla), probable causes of the observed decrease in fatty tissues over the past 15 years could be principally linked not only to the impact of contaminants (possibly endocrine-disrupting substances) but also to disease agents, alteration of food availability and other global changes in the environment (Belpaire et al. 2009; de Boer et al. 2010).

In the second place, the higher CB $118 / \mathrm{CB} 153$ ratios in flounder liver and muscle tissues were detected in the moderately contaminated population sampled in the Ster estuary which displayed a higher fish growth rate. A convergent result was obtained on the PCB contamination of eels collected in different sectors of the Gironde estuary, where the higher CB 118/CB 153 ratio could be related to the higher fish growth (Tapie et al. 2011). However, considering the CB 118/CB 153 ratio as a possible proxy of fish growth must be considered cautiously because the contrasted ratios between populations could be the result of complex interactions between diet, ecology, physiology and/or metabolization capacities of persistent organic pollutants.

The tile plot and the second axis of the RDA underlined a clear seasonal pattern in flounder responses to environmental stress. The tile plot, showing the distribution of individuals considering the factor constraints used in the analysis (estuary, season, gender) and $k$-means groups, underlined a reduced seasonal effect within the pristine site (the Ster) and a marked seasonal effect for the contaminated systems. We suggest that the convergent fish responses in the Vilaine, Loire and Gironde in winter could be mainly explained by a diffuse contamination increasing over the whole basins during this rainy season. Fish in these estuaries would thus be exposed to complex mixtures of pollutants that are not significantly different among these systems. On the other hand, diverging cocktails of pollutants and possible other stressors could be associated to the dry summer and could thus explain differential fish responses in the Loire-Gironde and Vilaine systems. 
The second axis of the RDA showed contrasted fish responses between winter and summer particularly linked (1) to various levels of gene expression for ferritin and BHMT and (2) to a global increase in summer of the expression level of Cyp450 1A1 and of the DNA damages in the polluted systems. In mammalian models, ferritin, the main iron storage protein exerts a cytoprotective effect against the iron-catalyzed production of reactive oxygen species and plays a complex role during hypoxia/reoxygenation events (Irace et al. 2005). Cyp450 1A1 is involved in phase I xenobiotics and drug metabolism (Williams et al. 2000), whereas BHMT has been recently proposed by some authors to be involved in phase II of detoxification, in particular of pesticides (Marchand et al. 2006; Evrard et al. 2010b).

The Vilaine estuary is periodically submitted to hypoxic conditions in the summer, mainly linked to the increasing temperature, eutrophication and to the retention/leak of waters by a dam located $12 \mathrm{~km}$ upstream from the mouth of the estuary (Menesguen et al. 2001). We suggest that (1) during the particularly dry and hot summer of 2005, the closure of the dam might have reduced the general flow of contaminants from the whole drainage basin to the estuary and (2) consequently, the Vilaine chemical stress could have been reduced and/or mainly linked to pesticides widely distributed in the downstream part of the estuary during summer (Marchand et al. 2006). This last hypothesis seems to be corroborated by our results since the within-estuary variation among season is higher in the Vilaine than in the other estuaries (Fig. 3). On the other hand, the Loire and Gironde individuals showed the lowest within-estuary, among-season variation.

For aquatic animals, changes in temperature, oxygen levels and numerous xenobiotics can cause oxidative stress in natural conditions by disrupting the balance between ROS production and elimination (Lushchak 2011); furthermore, hypoxia can induce oxidative DNA damage with higher levels of biological effects in fish (Mustafa et al. 2011). Thus, in the present study, considering the whole seasonal patterns observed for the flounder chemical signatures and biological responses to environmental stress, we suggest that the significant increase in DNA damage detected in summer could be linked to the synergetic effects of high temperatures, chemical stress and, possibly, hypoxia in particular estuaries. The major stressors conducting to DNA damages in summer could be temperature+hypoxia + pesticides in the Vilaine estuary and temperature+cocktail of contaminants in the Loire and Gironde systems.

The RDA did not show important differences in liver lesions between the estuaries and, thus, does not link them to the levels of chemical contamination. For example, a relative uniformity of the tumour+FCA frequency was detected in the Gironde, Loire and Ster populations (from
8.4 to $10 \%$ ), the Vilaine frequency being somewhat larger $(18.3 \%)$. The FCA frequency for the Vilaine is similar to those observed for flounder in highly polluted systems in Great Britain or in the Netherlands (Lyons et al. 2004; Vethaak and Wester 1996). In the present study, higher levels of liver inflammation were also observed in the four Bay of Biscay estuaries (from 10 to $53.3 \%$ ) compared to the frequency observed for the flounder in the Netherlands (from 2.9 to $31.4 \%$ in Vethaak and Wester 1996). We suggest that the relatively high frequencies of flounder liver lesions in the Bay of Biscay compared to England and the North Sea are not linked to a particular contamination context, but could be more likely linked to the localization of this Bay in the southern part of the flounder distribution area. Global warming is currently reducing the abundance of flounder in the Bay of Biscay (Hermant et al. 2010), and we suggest that, in this sector, liver pathologies are probably the consequence of an increasing multiple stresses in estuaries including the impacts of toxics and thermal stress, hypoxia and parasites.

\section{Conclusion}

This work underlines the pertinence of the European flounder as an excellent candidate species to monitor the quality of the coastal waters considering the loads of contaminants in fish tissue and a large set of markers focusing on different levels of organization. The spatial component of this study shows that an increasing contamination is correlated to an alteration of the energetic metabolism, possibly affecting some fitness-related parameters such as the condition index and growth rate. The analysis of the seasonal variability in the fish responses underlined differential responses between estuaries, particularly during summer when the sources of contaminants can be modified and when additional stress can appear in the field (thermal stress, hypoxia, etc.).

This study confirms that the integrative approach on flounder responses (from transcriptional and metabolic responses to physiology) conducted in several estuaries over Europe is particularly efficient to diagnose the general level of chemical stress (Williams et al. 2011). Furthermore, the present work carried out in southern Europe shows higher frequencies of liver lesions when compared to northern Europe and suggests that additional factors (thermal stress, hypoxia, etc.) might potentiate the impact of toxics on liver pathology. In the general context of global change, aquatic populations are increasingly subjected to multi-stress in their natural habitats, populations subjected to elevated temperatures becoming more susceptible to pollution (Lapointe et al. 2011). 
Acknowledgments This study was supported by the INTERREG program, DIESE, by the DEVIL-INERIS program and by the EVOLFISH project (ANR-VMCS)

\section{References}

Barreto RE, Gontijo AMMC, Alves-de-Lima RO, Raymundi VC, Pinhal D, Reyes VAV, Volpato GL, Salvadori DMF (2007) MS222 does not induce primary DNA damage in fish. Aquacult Int 15:163-168

Baumard P, Budzinski H, Garrigues P, Dizer H, Hansen PD (1999) Polycyclic aromatic hydrocarbons in recent sediments and mussels (Mytilus edulis) from Western Baltic Sea: occurrence, bioavailability and seasonal variations. Mar Environ Res 47:17-47

Belpaire CGJ, Goemans G, Geeraerts C, Quataert P, Parmentier K, Hagel P, de Boer J (2009) Decreasing eel stocks: survival of the fattest? Ecol Freshw Fish 18:197-214

Blanchet G, Legendre P, Borcard D (2008) Forward selection of explanatory variables. Ecology 89:2623-2632

Borcard D, Legendre P, Drapeau P (1992) Partialling out the spatial component of ecological variation. Ecology 73:1045-1055

Budzinski H, Papineau A, Baumard P, Garrigues P (1995) Extraction assistée par chauffage microondes focalisées (MOF) à pression ambiante des composés organiques dans les matrices naturelles: application à l'analyse des composés organiques. CR Acad Sci Paris 321(série IIb):69-76

Budzinski H, Letellier M, Thompson S, Le Menach K, Garrigues P (2000) Combined protocol for the analysis of polycyclic aromatic hydrocarbons (PAHs) and polychlorobiphenyls (PCBs) from sediments using focussed microwave assisted (FMW) extraction. Fresenius J Anal Chem 367:165-171

Cachot J, Cherel Y, Larcher T, Pfohl-Leszkowicz A, Laroche J, Quiniou L, Morin J, Schmitz J, Burgeot T, Pottier D (2012) Histopathological lesions and DNA adducts in the liver of European flounder (Platichthys flesus) collected in the Seine estuary vs two reference estuarine systems on the French Atlantic coast. Environ Sci Pollut R (this issue)

Calinski T, Harabasz J (1974) A dendrite method for cluster analysis. Commun Stat 3:1-27

Cambier S, Bénard G, Mesmer-Dudons N, Gonzalez P, Rossignol R, Brèthes D, Bourdineaud JP (2009) At environmental doses, dietary methylmercury inhibits mitochondrial energy metabolism in skeletal muscles of the zebra fish (Danio rerio). Int J Biochem Cell Biol 41(4):791-799

de Boer J, Dao QT, van Leeuwen SPJ, Kotterman MJJ, Schobben JHM (2010) Thirty year monitoring of PCBs, organochlorine pesticides and tetrabromodiphenylether in eel from the Netherlands. Environ Pollut 158:1228-1236

Depledge MH (1994) The rationale basis for the use of biomarkers as ecotoxicological tools. In: Fossi MC, Leonzio C (ed) Non destructive biomarkers in vertebrates. Lewis Publishers, Boca Raton, FL, pp 271-296

Dray S, Legendre P, Blanchet FG (2009) packfor: forward selection with permutation (Canoco p. 46). R package version $0.0-7 / \mathrm{r} 58$. http://R-Forge.R-project.org/projects/sedar/

Evrard E, Devaux A, Bony S, Burgeot T, Riso R, Budzinski H, Le Du M, Quiniou L, Laroche J (2010a) Responses of the European flounder Platichthys flesus to the chemical stress in estuaries: load of contaminants, gene expression, cellular impact and growth rate. Biomarkers 15(2):111-127

Evrard E, Marchand J, Théron M, Pichavant-Rafini K, Durand G, Quiniou L, Laroche J (2010b) Impact of mixtures of herbicides on molecular and physiological responses of the European flounder Platichthys flesus. Comp Biochem Physiol C 152:321-331
Feist SW, Lang T, Stentiford GD, Koehler A (2004) Use of liver pathology of the European flatfish dab (Limanda limanda L.) and flounder (Platichthys flesus L.) for monitoring. ICES techniques in marine environmental sciences 38. ICES, Copenhagen

Forget J (1998) Impact neurotoxique de contaminants (pesticides et métaux) sur un crustacé marin Tigriopus brevicornis (Müller), Caractérisation de la cholinestérase et application à la surveillance des effets des polluants sur l'environnement marin. $\mathrm{PhD}$ thesis, Univ. Paris VI

Frenzili G, Nigro M, Lyons BP (2009) The Comet assay for the evaluation of genotoxic impact in aquatic environments. Mutat Res 681:80-92

Guimaraes L, Medina MH, Guilhermino L (2012) Health status of Pomatoschistus microps populations in relation to pollution and natural stressors: implication for ecological risk assessment. Biomarkers 17(1):62-77

Hagger JA, Jones MB, Leonard DRP, Owen R, Galloway TS (2006) Biomarkers and integrated environmental risk assessment: are there more questions than answers? Integr Environ Assess Manag 2(4):312-329

Hagger JA, Jones MB, Lowe D, Leonard DRP, Owen R, Galloway TS (2008) Application of biomarkers for improving risk assessments of chemicals under the water framework directive: a case study. Mar Pollut Bull 56:1111-1118

Hermant M, Lobry J, Bonhommeau S, Poulard JC, Le Pape O (2010) Impact of warming on abundance and occurrence of flatfish populations in the Bay of Biscay (France). J Sea Res 64:45-53

Höher N, Köhler A, Strand J, Broeg K (2012) Effects of various pollutant mixtures on immune responses of the blue mussel (Mytilus edulis) collected at a salinity gradient in Danish coastal rivers. Mar Environ Res 75:35-44

ICES (2011) OSPAR request - further development of guidance on integrated monitoring and assessment of chemicals and biological effects. Special Request Advice June 2011, Book 1

Irace C, Scorziello A, Maffettone C, Pignataro G, Matrone C, Adornetto A, Santamaria R, Annunziato L, Colonna A (2005) Divergent modulation of iron regulatory proteins and ferritin biosynthesis by hypoxia/reoxygenation in neurons and glial cells. J Neurochem 95:1321-1331

Kannan N, Reusch TBH, Schulz-Bull DE, Petrick G, Duinker JC (1995) Chlorobiphenyls: model compounds for metabolism in food chain organisms and their potential use as ecotoxicological stress indicators by application of the metabolic slope concept. Environ Sci Technol 29:1851-1859

Lapointe D, Pierron F, Couture P (2011) Individual and combined effects of heat stress and aqueous or dietary copper exposure in fathead minnows (Pimephales promelas). Aquat Toxicol 104:80-85

Legendre P (2007) Studying beta diversity: ecological variation partitioning by multiple regression and canonical analysis. J Plant Ecol 31:976-981

Legendre P, Anderson MJ (1999) Distance-based redundancy analysis: testing multi-species responses in multi-factorial ecological experiments. Ecol Monogr 69:1-24

Lushchak VI (2011) Environmentally induced oxidative stress in aquatic animals. Aquat Toxicol 101(1):13-30

Lyons BP, Stentiford GD, Green M, Bignell J, Bateman K, Feist SW, Goodsir F, Reynolds WJ, Thain JE (2004) DNA adduct analysis and histopathological biomarkers in European flounder (Platichthys flesus) sampled from UK estuaries. Mutat Res 552:177-186

Lyons BP, Thain JE, Stentiford GD, Hylland K, Davies IM, Vethaak AD (2010) Using biological effects tools to define good environmental status under the European Union Marine Strategy Framework Directive. Mar Poll Bull 60:1647-1651

Marchand J, Quiniou L, Riso R, Thebaut MT, Laroche J (2004) Physiological cost of tolerance to toxicants in the European flounder Platichthys flesus, along the French Atlantic coast. Aquat Toxicol 70:327-343 
Marchand J, Tanguy A, Charrier G, Quiniou L, PLee-Gauthier E, Laroche J (2006) Molecular identification and expression of differentially regulated genes of the European flounder, Platichthys flesus, submitted to pesticide exposure. Mar Biotechnol 8:275-294

Martinez-Gomez C, Vethaak AD, Hylland K, Burgeot T, Köhler A, Lyons BP, Thain J, Gubbins MJ, Davies IM (2010) A guide to toxicity assessment and monitoring effects at lower levels of biological organization following marine oil spills in European waters. ICES J Mar Sci 67(6):1105-1118

Menesguen A, Aminot A, Belin C, Chapelle A, Guillaud JF, Joanny M, Lefebvre A, Merceron M, Piriou JY, Souchu P (2001) L'eutrophisation des eaux marines et saumâtres en Europe en particulier en France. Rapport IFREMER pour la Commission EuropéenneDG.ENV.BI. p. 59

Meyer D, Zeileis A, Hornik K (2010) vcd: visualizing categorical data. $\mathrm{R}$ package version 1.2-9

Mustafa SA, Al-Subiai SN, Davies SJ, Jha A (2011) Hypoxia-induced oxidative DNA damage links with higher level biological effects including specific growth rate in common carp, Cyprinus carpio L. Ecotoxicology 20:1455-1466

Oksanen, J, Blanchet FG, Kindt R, Legendre P, O'Hara RB, Simpson GL, Solymos P, Stevens MHH, Wagner H (2010) vegan: community ecology package. $\mathrm{R}$ package version $1.17-$ 4. http://CRAN.R-project.org/package=vegan

Peres-Neto P, Legendre P, Dray S, Borcard D (2006) Variation partitioning of species data matrices: estimation and comparison of fractions. Ecology 87(10):2614-2625

R Development Core Team (2010) R: a language and environment for statistical computing. R Foundation for Statistical Computing, Vienna, Austria. ISBN 3-900051-07-0. http://www.R-project.org

Riso RD, Le Corre P, Chaumery CJ (1997a) Rapid and simultaneous analysis of trace metals $(\mathrm{Cu}, \mathrm{Pb}$ and $\mathrm{Cd})$ in seawater by potentiometric stripping analysis. Anal Chim Acta 351:83-89

Riso RD, Monbet P, Le Corre P (1997b) Measurement of copper in sea-water by constant current stripping analysis (CCSA) with a rotating gold disk electrode. Analyst 122:1593-1596

SGIMC (2011) Report of the Joint ICES/OSPAR Study Group on Integrated Monitoring of Contaminants and Biological Effects (SGIMC). 14-18 March 2011, Copenhagen, Denmark, ICES Advisory Committee: ICES CM 2011/ACOM:30

Singh N, MCCoy M, Tice R, Schneider E (1988) A simple technique for quantitation of low levels of DNA damage in individual cells. Exp Cell Res 175:184-191

Sokolova IM, Sokolov EP, Ponnappa KM (2005) Cadmium exposure affects mitochondrial bioenergetics and gene expression of key mitochondrial proteins in the eastern oyster Crassostrea virginica Gmelin (Bivalvia: Ostreidae). Aquat Toxicol 73:242-255

Stentiford GD, Longshaw M, Lyons BP, Jones G, Green M, Feist SW (2003) Histopathological biomarkers in estuarine fish species for the assessment of biological effects of contaminants. Mar Environ Res 55:137-159

Tankoua OF, Buffet PE, Amiard JC, Amiard-Triquet C, Mouneyrac C, Berthet B (2011) Potential influence of confounding factors (size, salinity) on biomarkers in the sentinel species Scobicularia plana used in programmes monitoring estuarine quality. Environ Sci Pollut Res 18(8):1253-1263

Tapie N (2006) Contamination des écosystèmes aquatiques par les PCB et PBDE: application à l'estuaire de la Gironde. $\mathrm{PhD}$ thesis, Univ. Bordeaux 1, $276 \mathrm{pp}$

Tapie N, Budzinski H, Le Ménach K (2008) Fast and efficient extraction methods for the analysis of PCBS and PBDEs in biological matrices. Anal Bioanal Chem 391:2169-2177

Tapie N, Le Menach K, Pasquaud S, Elie P, Dévier MH, Budzinski H (2011) PBDE and PCB contamination of eels from the Gironde estuary: from glass eels to silver eels. Chemosphere $83: 175-185$

Templ M, Alfons A, Kowarik A (2010) VIM: visualization and imputation of missing values. $\mathrm{R}$ package version 1.4.1. http:// CRAN.R-project.org/package=VIM

ter Braak CJF (1988) Partial canonical correspondence analysis. In: Block HH (ed) Classification and related methods of data analysis. North Holland Press, Amsterdam, pp 551-558

Thain JE, Vethaak AD, Hylland K (2008) Contaminants in marine ecosystems: developing an integrated indicator framework using biological-effect techniques. ICES J Mar Sci 65:1508-1514

Thompson S, Budzinski H, Garrigues P, Narbonne JF (1999) Comparison of PCB and DDT distribution between water-column and sediment-dwelling bivalves in Arcachon Bay, France. Mar Pollut Bull 38(8): 655-662

van den Wollenberg AL (1977) Redundancy analysis. An alternative for canonical correlation analysis. Psychometrika 42:207-219

Vethaak AD, Wester PW (1996) Diseases of flounder Platichthys flesus in Dutch coastal and estuarine waters, with particular reference to environmental stress factors. II. Liver histopathology. Dis Aquat Org 26:99-116

Vethaak AD, Jol JG, Martinez-Gomez C (2011) Effects of cumulative stress on fish health near freshwater outlet sluices into the sea: a case study (1988-2005) with evidence for a contributing role of chemical contaminants. Integr Environ Assess Manag 7:445-458

Williams TD, Lee JS, Sheader DL, Chipman JK (2000) The cytochrome P450 1A gene (CYP1A) from European flounder (Platichthys flesus) analysis of regulatory regions and development of a dual luciferase reporter gene system. Mar Environ Res 50:1-6

Williams TD, Turan N, Diab AM et al (2011) Towards a system level understanding of non-model organisms sampled from the environment: a network biology approach. PLoS Comput Biol 7(8): e1002126 